\title{
Human Cord Blood Leukocyte Innate Immune Responses to Defense Collagens
}

\author{
HIDEKI MARUYAMA, MANUEL GALVAN, FEIZAL WAFFARN, AND ANDREA J. TENNER
}

Division of Neonatology, Department of Pediatrics [H.M., F.W.]; and Department of Molecular Biology and Biochemistry [M.G., A.J.T.], University of California, Irvine 92697-3900, U.S.A.

\begin{abstract}
The innate immune system provides critical protection during initial infections before the generation of an appropriate adaptive (antibody or $\mathrm{T}$ cell mediated) immune response. These early defense mechanisms may be particularly critical for neonates in whom the adaptive immune system is not fully operational. Pattern recognition molecules target potential pathogens for destruction by the innate immune system, and likely facilitate the initiation of a pathogen-specific immune response. Defense collagens, such as C1q, MBL and SPA, comprise a family of such proteins that, via specific interactions with phagocytic cells, play a role in this first line of defense. To begin to assess the importance of these innate defense mechanisms in neonates, cord blood plasma and leukocytes were isolated, and responses to these components of the innate defense system were assessed. C1q enhanced the phagocytosis of targets suboptimally opsonized with either IgG or complement components, and this enhancement of phagocytosis was blocked by anti-CD93/C1qR MAb by $57 \%$ to $68 \%$. Flow cytometric analysis demonstrated that neonatal monocytes and neutrophils expressed CD93/C1qR similarly to adult cells, with several-fold greater expression on monocytes than on neutrophils and essentially no expression on
\end{abstract}

\section{ABSTRACT}

lymphocytes. Superoxide production in response to multivalent C1q by neonatal neutrophils was also comparable to adult cells. We also confirm that $\mathrm{C} 1 \mathrm{q}$ and $\mathrm{MBL}$ are present in neonate circulation. Thus, the data demonstrate that these recognition and effector mechanisms of the innate system are functional in the newborn and similar to that of adult cells. (Pediatr Res 54: 724-731, 2003)

$\quad$ Abbreviations
HBSS, Hank's balanced salt solution
HSA, human serum albumin
MBL, mannan binding lectin
PBL, peripheral blood mononuclear leukocytes
PMNL, polymorphonuclear leukocytes
E, sheep erythrocytes
EA
EAgG, E coated with IgG anti-E
NHS, normal human serum
PDBu, phorbol dibutyrate
PI, phagocytic index
SPA and SPD, surfactant protein A and D

The innate immune system, which includes anti-microbial proteins and peptides, complement proteins, phagocytes, natural killer cells and other recognition and effector elements, is physiologically critical at initial stages of infection when little or no adaptive response is present. These defense mechanisms may be particularly consequential in neonates who are at risk for infections and in whom the adaptive immune system (antibodies and T cell mediated immunity) is not fully developed. Two structurally similar proteins, the classical comple-

Received January 16, 2003; accepted March 19, 2003.

Correspondence: Andrea J. Tenner, Ph.D., 3205 McGaugh Hall, Department Molecular Biology and Biochemistry, University of California, Irvine, CA, 92697, U.S.A.; e-mail: atenner@uci.edu

These studies were supported by a grant from NIH AI41090 (AJT). Support for obtaining human blood products used in this study was provided in part by Public Health Service research grant M01 RR00827 from the National Center for Research Resources.

Current address (H.M.): Division of Neonatology, Perinatal Medical Center, Kagoshima City Hospital, 20-17, Kajiya-cho, Kagoshima City, 892-8580, Japan.

DOI: 10.1203/01.PDR.0000085804.00768.4D ment recognition protein, $\mathrm{Clq}$, and $\mathrm{MBL}$, mannose binding lectin, have been shown to play a protective role against infection $(1,2)$, both via their ability to activate the complement cascade and via their ability to enhance phagocytosis. $\mathrm{CD} 93 / \mathrm{C} 1 \mathrm{qR}_{\mathrm{P}}$ is a cell surface glycoprotein predominantly expressed on myeloid cells, endothelial cells, and stem cells that influences cellular responses to $\mathrm{Clq}, \mathrm{MBL}$ and other defense collagens, namely the enhancement of phagocytosis of suboptimally opsonized targets (3) (and reviewed in (4)). C1q has also been shown to trigger the generation of superoxide when presented as a multivalent ligand to adult human neutrophils (5) via a CD18-dependent mechanism $(6,7)$.

Mutations in MBL, mannose binding lectin (also known as MBP, mannose binding protein), have been implicated as predisposing young children toward infections (8), and more recently has been correlated with an increase number and length of infections in children immunocompromised by cancer chemotherapy (9). Similarly, C1q deficiencies lead to increased childhood infections (10). While this susceptibility 
could be related to the inability to activate the complement cascade, the inability to stimulate the innate immunity by enhancing phagocytosis of infectious microbes may also contribute to the functional immune deficiency.

In this study, newborn cord blood neutrophils and monocytes were analyzed for functional responses to C1q. In the process of assessing monocyte phagocytic function, we developed, and report here, a procedure for sorting newborn cord blood mononuclear cells using forward and side scatter to obtain a purified monocyte population. In addition, the expression and activity of $\mathrm{CD} 93 / \mathrm{ClqR}_{\mathrm{P}}$ on neonatal leukocytes was assessed. These innate immune response mechanisms were found to be similar to that of adult cells. That is, C1q enhanced monocyte ingestion of suboptimally opsonized targets, and that enhancement was inhibited by $\mathrm{MAb}$ to $\mathrm{CD} 93 / \mathrm{C} 1 \mathrm{qR}$, but not irrelevant isotype control antibodies. In addition, C1q triggered the production of superoxide in neutrophils purified from newborn blood, again similar to adults. The data demonstrate that these innate immune defense mechanisms are functional in neonates, providing a potential for the design of therapeutic targeting of these mechanisms to enhance protection of newborns from infection (11).

\section{MATERIALS AND METHODS}

Media, reagents and antibodies. $\mathrm{C} 1 \mathrm{q}$ was purchased from Advanced Research Technologies (San Diego, CA, U.S.A.) or isolated from plasma-derived human serum by the method of Tenner et al. (12) modified as described (13). The preparations used were fully active as determined by hemolytic titration and homogeneous as assessed by SDS-PAGE. Protein concentration was determined using an extinction coefficient (E1\%) at $280 \mathrm{~nm}$ of 6.8 for C1q (14).

Anti-CD93/C1qR $\mathrm{PAbs}$ R139 ( $\left.\mathrm{IgG}_{2 \mathrm{~b}}\right)$ and R3 (IgM), generated using $\mathrm{Clq}$ binding proteins as the immunogen (15), were purified before use as previously described (16). Monoclonal anti-MBL antibody 2A9, h1.2 and 3F8 were a generous gift from Dr. Gregory Stahl, Harvard Medical School, Boston (17). Polyclonal anti-MBL, anti-serum 1173, was derived after immunization with MBL, which was purified from normal human serum (N.S.) The $\mathrm{IgG}$ fraction was purified using octanoic acid and ammonium sulfate. IgM antibodies against sheep red blood cells were purchased from Diamedix (Miami, FL, U.S.A.). Antibodies against sheep red cells (hemolysin) were purchased from Cordis Laboratories (Miami, FL, U.S.A.) and $\operatorname{IgG}$ was purified from hemolysin using a Protein-G column.

Pyrogen-free water (MilliQ-Plus) was used for all laboratory buffers and reagent preparation. LSM (lymphocyte separation media) was purchased from ICN Biochemicals Inc., (Aurora, OH, U.S.A.). Human serum albumin (HSA) was produced by Baxter/Hyland, Glendale, CA, U.S.A. and obtained from FFF Enterprises (Temecula, CA, U.S.A.). Each lot of HSA was screened before use for activation of the monocyte population to avoid elevated baseline levels of phagocytosis. All other reagents used, except where noted otherwise, were obtained in the highest quality available from Sigma Chemical Co. (St. Louis, MO, U.S.A.).
Isolation of leukocytes. Cord blood samples were prospectively collected at the time of delivery from 18 uncomplicated singleton pregnancies. The infants gestational ages ranged from $38-41$ wk and birth weights ranged from $2650-4460 \mathrm{~g}$ All cord blood samples were added to EDTA within 3-5 min of delivery such that the final concentration was $20 \mathrm{mM}$. Adult blood was drawn from normal volunteers into EDTA syringes (final concentration, $20 \mathrm{mM}$ EDTA) or from units of blood collected from UCI Medical Center, Orange, California, U.S.A., for experimental use (informed consent obtained). All blood samples were collected, in accordance with the guidelines and approval of the UCI Institutional Review Board.

Buffy coats from units or cord blood samples were diluted 1:1 in PBS-1 mM EDTA and separated by centrifugation on LSM cushions. To obtain polymorphonuclear leukocytes (PMN), the red cell fraction was subjected to Dextran T500 (Pharmacia) sedimentation according to the method of Boyum (18), modified as described (19). The residual red blood cells were removed by hypotonic lysis, and the cells were washed into HBSS containing $1 \mathrm{mM} \mathrm{Ca}++$ and $\mathrm{Mg}++(\mathrm{HBSS}++)$.

To obtain adult peripheral blood monocytes, the LSM mononuclear cell layer was washed once with PBS-1mM EDTA (to reduce platelets) and subsequently subjected to counterflow elutriation using a modification of an original technique (20) as described (21). To obtain monocytes from the small volumes of cord blood, mononuclear cells recovered on the LSM gradient were washed once in PBS-EDTA and applied to a second LSM cushion to reduce granulocyte contamination. The mononuclear cells were then washed $3 \mathrm{X}$ with a solution of HBSS$0.01 \mathrm{M}$ EDTA containing $0.3 \%$ HSA (Sort buffer) to reduce platelets and residual LSM or plasma. The cells were then resuspended in Sort buffer to a final cell concentration of $15 \times$ $10^{6} / \mathrm{mL}$. Before sort, the cell suspension was passed through Cell-Strainer Cap (Falcon, 35-2235. Becton Dickinson Labware, Franklin Lakes, NJ, U.S.A.) to remove cell aggregates. Monocytes were separated from other mononuclear cells by their characteristic forward and side scatter profile on a Mo-Flo Flow cytometric sorter (Cytomation, Fort Collins, CO, U.S.A.), at a flow rate of 6000 cells/s. Forward and pulse width analysis was also incorporated to exclude cell aggregates in the collected sort product. Sorted monocytes were collected in Falcon $12 \times 75 \mathrm{~mm}$ polypropylene round bottom tubes. Before phagocytosis experiments the monocytes were washed $2 \times$ in sort buffer and finally resuspended in phagocytosis buffer at 2.5 $\times 10^{5} / \mathrm{mL}$

Flow cytometric and fluorescence analysis. PMN or mononuclear cells were resuspended in FACS buffer (HBSS containing $1 \mathrm{mM} \mathrm{Mg}^{2}+, 1 \mathrm{mM} \mathrm{Ca}^{2}+, 0.2 \%$ BSA, $0.2 \%$ sodium azide) to $10^{6} / 100 \mu \mathrm{L}$ and incubated with $5 \mu \mathrm{g}$ of primary antibody or control murine immunoglobulin (Sigma Chemical Co.) for $30 \mathrm{~min}$ on ice. After washing three times in FACS buffer, the cells were incubated with FITC-conjugated donkey anti-murine IgG or IgM (Jackson ImmunoResearch Laboratories, Inc., West Grove, PA, U.S.A.) as appropriate for $30 \mathrm{~min}$ on ice. After washing cells three times in FACS buffer, cell associated fluorescence was measured using FACSCalibur (Becton Dickinson, Bedford, MA, U.S.A.). 
Phagocytosis Assay. Target particles for the phagocytosis assay were sheep erythrocytes (E) suboptimally opsonized with either IgG anti-sheep red blood cells $\left(\mathrm{EA}_{\mathrm{IgG}}\right)$ or IgM and complement prepared as previously described (22) to assess FcR-mediated and CR1-mediated phagocytosis respectively. Briefly, eight-well Lab Tek chambers (Nalge Nunc International, Naperville, IL, U.S.A.) were coated with varying concentrations of $\mathrm{Clq}$ or the control protein, human serum albumin (HSA). Phagocytic cells resuspended at $2.5 \times 10^{6} / \mathrm{mL}$ in phagocytosis buffer (RPMI, supplemented with $2 \mathrm{mM}$ Lglutamine, $10 \mu \mathrm{g} / \mathrm{mL}$ pen/strep, $5 \mathrm{mM} \mathrm{MgCl}$, and $10 \mathrm{mM}$ HEPES) are added to each chamber $(250 \mu \mathrm{L} /$ well $)$, the cells centrifuged at $700 \mathrm{rpm}$ (RT6000, Dupont Sorvall) for $3 \mathrm{~min}$ and subsequently placed at $37^{\circ} \mathrm{C}$ in $5 \% \mathrm{CO}_{2}$ for $30 \mathrm{~min}$. Targets were then added $\left(10^{7} / 100 \mu \mathrm{L}\right)$, the slides again subjected to centrifugation ( $700 \mathrm{rpm}, 3 \mathrm{~min}$ ), and incubated for 30 min at $37^{\circ} \mathrm{C}$. After removing unbound targets by washing, bound, uningested targets were removed by hypotonic lysis (23). Cells were then fixed in freshly diluted $1 \%$ glutaraldehyde (Ted Pella, Inc., Redding, CA, U.S.A.) and stained with Giemsa. Phagocytosis was quantitated using light microscopy. In some experiments, MAb was incubated with the monocytes for $15 \mathrm{~min}$ at room temperature before adding to the wells. The number of E-targets ingested per 100 effector cells was defined as the phagocytic index (PI), whereas the percentage of effector cells ingesting at least one E-target was defined as the percent phagocytosis. Over 200 effector cells were scored per well and duplicate sample wells per condition were used for each experiment.

Measurement of superoxide production. $\mathrm{O}_{2}^{-}$was measured by the superoxide dismutase-inhibitable reduction of cytochrome $c$ adapted to a microplate format (24). Ninety six-well Immulon 2 plates (Dynatech Laboratories, Chantilly, VA, U.S.A.) were coated with $10-300 \mu \mathrm{g} / \mathrm{mL} \mathrm{C1q}$ or test protein/ fragments diluted in PBS for 2-3 h at room temperature. After washing the plate with PBS, the reaction was started by the addition of $100 \mu \mathrm{L}$ of neutrophil suspension $\left(3.5 \times 10^{6} / \mathrm{mL}\right)$ to the microtiter wells containing $100 \mu \mathrm{L}$ of cytochrome $c$ reaction mixture $(200 \mu \mathrm{M}$ cytochrome $c$ in Hanks balanced salt solution containing $1 \mathrm{mM} \mathrm{Ca}^{2+}$ and $1 \mathrm{mM} \mathrm{Mg}^{2+}$ ). $\mathrm{A}_{550}$ was recorded every $30 \mathrm{~s}$ at $37^{\circ} \mathrm{C}$ using a ThermoMax kinetic microplate reader (Molecular Devices, Inc., Menlo Park, CA, U.S.A.) equipped with a $1.0 \mathrm{~nm}$ bandpass filter. The initial absorbance value was subtracted from each subsequent reading, and this value converted to nmoles of $\mathrm{O}_{2}{ }^{-}$using an extinction coefficient of $0.022 \mu \mathrm{M}^{-1} \mathrm{~cm}^{-1}$. Phorbol dibutyrate $(200 \mathrm{ng} / \mathrm{mL})$ was used as a positive control stimulus. Control samples containing superoxide dismutase $(40 \mu \mathrm{g} / \mathrm{mL}$ final concentration) were always run in parallel with each sample, and showed no change in $\mathrm{A}_{550}$ under any condition tested (not shown).

ELISAs for C1q and MBL. Serum or plasma concentrations of $\mathrm{Clq}$ and MBL were determined by sandwich ELISA as previously described $(25,26)$. Briefly, microtiter plates were coated with polyclonal anti-C1q or anti-MBL antibody at a concentration of 5-10 $\mu \mathrm{g} / \mathrm{mL}$ in coating buffer $(0.1 \mathrm{M}$ carbonate buffer, $\mathrm{pH} 9.6)$, respectively, (100 $\mu \mathrm{L} /$ well) and incubated overnight at $4{ }^{\circ} \mathrm{C}$. The microtiter plates were washed three times with PBS containing $0.05 \%$ Tween-20 (PBS-T) and blocked for $1 \mathrm{~h}$ at $37^{\circ} \mathrm{C}$ by adding $200 \mu \mathrm{L}$ of PBS containing $3 \%$ milk to each well. Samples and MBL or C1q standards were loaded into wells in duplicate, incubated at room temperature for $2 \mathrm{~h}$, and washed as above. Monoclonal anti-MBL $(2$ $\mu \mathrm{g} / \mathrm{mL}$ ) or affinity purified biotinylated anti-C1q diluted in PBST-1\% milk (100 $\mu \mathrm{L} /$ well) was added to each well and incubated at room temperature for $1 \mathrm{~h}$. After washing, plates were incubated with peroxidase conjugated donkey anti-mouse IgG (Jackson ImmunoResearch Laboratories, West Grove, PA, U.S.A.) or avidin -glucose oxidase for $30 \mathrm{~min}$ at room temperature. Color was developed using OPD or ABTS as the substrate, and reading the absorbance at $405 \mathrm{~nm}$ on a micro plate reader (Molecular Devices, Menlo Park, CA, U.S.A.). Serum MBL standard, kindly provided by Prof. Kawasaki (Kyoto University, Kyoto, Japan), was used to calibrate our plasma standard.

Hemolytic Titer for C1q. Two microliters of various dilutions of cord blood plasma was added to $300 \mu \mathrm{L}$ of a 1:30 dilution of human serum depleted of $\mathrm{C} 1 \mathrm{q}$ by passage over a BioRex 70 column (12). $80 \mu \mathrm{L}$ of sheep erythrocytes coated with anti sheep RBC (hemolysin) was then added and the samples incubated at $37^{\circ} \mathrm{C}$, for $30 \mathrm{~min}$. After addition of 1.6 $\mathrm{mL}$ ice cold $\mathrm{GVB}++$, the samples were pelleted and $\mathrm{OD}_{412}$ of the supernatant was measured (12).

\section{RESULTS}

C1q triggers enhancement of phagocytosis in cord blood monocytes. To assay the ability of defense collagens to enhance phagocytosis of suboptimally opsonized targets in vitro, isolation of a predominantly monocyte population without activating the phagocytes is required. While, with adult blood, monocytes are isolated via counter current elutriation, the volume of starting blood from cord blood precludes that methodology. Preliminary studies developed a method using forward (size) and side (granularity) scatter in a Mo-Flo cell sorter to isolate monocytes from small volumes of blood. Monocytes prepared from adult peripheral blood mononuclear leukocytes by this sorting procedure phagocytosed and responded to $\mathrm{Clq}$ to the same degree as cells isolated by elutriation (data not shown), and thus monocytes were isolated from cord blood using the sorting procedure. To prevent activation due to either aggregation of the monocytes or degranulation of platelets, the sorting was performed in the presence of EDTA. While the yield of monocytes varied among the cord blood samples $(2 \%$ to $10 \%$ of the starting mononuclear cells), one can anticipate 2 million monocytes obtained from $35-45 \mathrm{~mL}$ of cord blood. A typical forward and side scatter profile of the population before and after sorting is shown in Fig. 1, demonstrating a relatively homogeneous population obtained after sorting, with a range of $76 \%$ to $98 \%$ monocytes and an average of $84 \pm 9.6 \%(n=18)$ monocytes in the sorted population (Fig. 1, R2). Monocytes were then washed into phagocytosis buffer and assayed for phagocytosis as described in Materials and Methods.

Cord blood monocytes from all samples responded to interaction with $\mathrm{C} 1 \mathrm{q}$ with an enhancement of FcR-mediated phagocytosis. A photomicrograph of a representative experiment 
A

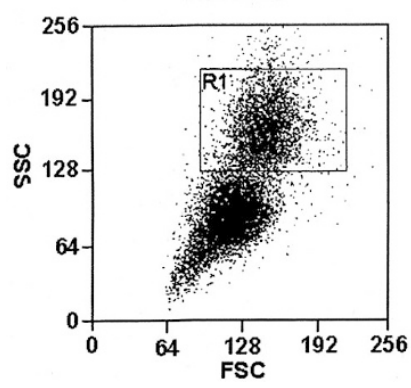

B

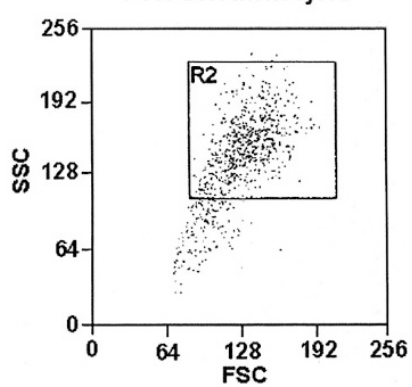

Figure 1. Monocytes display characteristic light scattering properties that are used as parameters to sort highly enriched monocyte populations from available cord blood samples. Forward and side scatter profile of mononuclear leukocyte population before $(A)$ and after $(B)$ sorting on a Mo-Flo Fluorescence activated cell sorter (Cytomation, Fort Collins, CO, U.S.A.). Forward and pulse width analysis was also incorporated to exclude cell aggregates in the collected sort product.

shows the typical enhancement of IgG coated targets (FcRmediated ingestion) (Fig. 2, $A, B$ ). Over 200 cells are scored per condition in duplicate, and the data are quantitatively presented as both the percent of monocytes that have ingested even one target (\% phagocytosis) (Fig. 2C) and the number of targets ingested per 100 monocytes (phagocytosis index) (Fig. 2D).
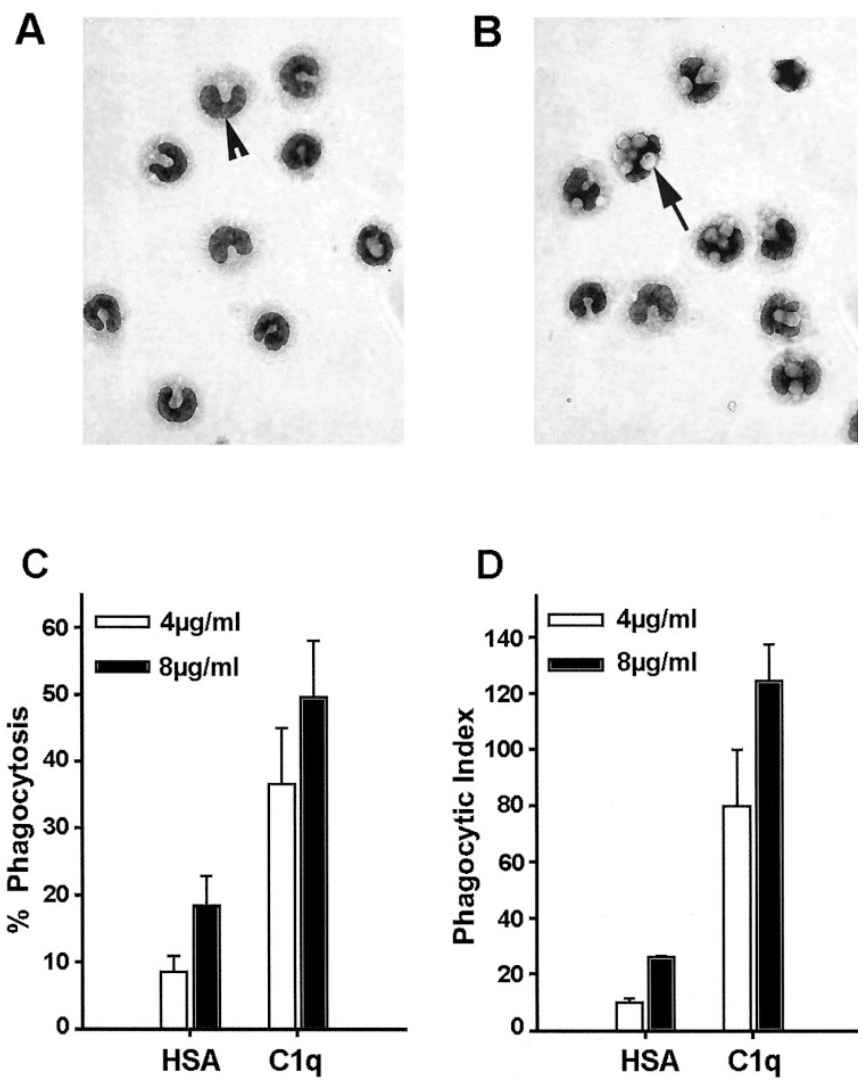

Figure 2. C1q enhances uptake of suboptimally opsonized sheep erythrocytes by cord blood monocytes. Micrographs depicting cord blood monocytes (stained with Giemsa, arrow in $A$ ) adhered to HSA $(A)$ and C1q $(B)$ (coating concentration of $4 \mu \mathrm{g} / \mathrm{ml}$ ) ingesting suboptimally opsonized $\mathrm{EA}_{\mathrm{IgG}}$ (arrowhead in $B)$. (C,D) Quantitative analysis of phagocytosis data. Values shown are averages of two wells in which over; 200 cells were scored. Data are representative of 7 distinct experiments.

Quantitative analysis of 7 similar experiments in which 4 $\mu \mathrm{g} / \mathrm{mL}$ or $8 \mu \mathrm{g} / \mathrm{mL}$ HSA or $\mathrm{Clq}$ was used as the protein coating concentration demonstrated that $\mathrm{C} 1 \mathrm{q}$ induced a $3.5 \pm$ 0.5 fold and $4.2 \pm 1.3$ fold increase in $\%$ phagocytosis and 7.0 \pm 2.5 fold and $5.9 \pm 2.1$ fold increase in the phagocytic index, respectively, over the HSA control. Similar enhancement of phagocytosis was seen with two additional experiments in which targets were coated with IgM and $\mathrm{C} 4 \mathrm{~b}$ to permit CR-1 mediated ingestion rather than FcR mediated phagocytosis. The fold increase in CR1-mediated phagocytosis mediated by Clq was $1.9 \pm 0.3$ (\% phagocytosis) and $2.3 \pm 0.1$ fold (phagocytic index) $(n=2)$.

Surface expression of CD93/C1qR. FACS analysis demonstrated that $\mathrm{CD} 93 / \mathrm{C} 1 \mathrm{qR} \mathrm{R}_{\mathrm{P}}$ is expressed on monocytes and polymorphonuclear leukocytes derived from cord blood of normal term deliveries. As with adult cells derived from peripheral blood (15), $\mathrm{CD} 93 / \mathrm{C} \mathrm{qR}_{\mathrm{P}}$ surface expression is considerably higher (6- to 8-fold higher) on monocytes than on neutrophils (Table 1). Figure 3 presents representative data demonstrating both R139 and R3 reactivity on monocytes and neutrophils. When gating on lymphocytes (as distinguished by side and forward scatter), R139 or R3 reactivity was either not detectable or not significantly above background, again identical to that seen in adult peripheral blood (15). Cord blood PMN reactivity with R139 and R3 appeared slightly lower than that seen with adult blood PMN run in parallel (Table 1). In contrast, the level of reactivity of R139 on neonatal monocytes was nearly identical to adults, while R3 reactivity was significantly $(p=0.03)$ higher on cord blood monocytes than that normally seen with adult blood. The basis for the difference in reactivity of the R3 (IgM) and R139 $\left(\operatorname{IgG}_{2 b}\right)$ (which bind distinct domains on $\mathrm{CD} 93 / \mathrm{ClqR}_{\mathrm{P}}$ ) for adult versus neonate monocytes is not known.

The C1q-mediated enhancement of phagocytosis was shown to be influenced by the cell surface $\mathrm{CD} 93 / \mathrm{ClqR}_{\mathrm{P}}$ since preincubation with anti-CD93/C1qR antibody (R139) with monocytes before adherence to $\mathrm{C} 1 \mathrm{q}$ inhibits the enhancement of ingestion by $56.6 \pm 1 \%$ (\% phagocytosis) and $67.7 \pm 0.8 \%$ (phagocytic index) ( $n=2)$ (Fig. 4).

Neutrophils isolated from cord blood are stimulated to produce superoxide anion upon interaction with C1q. A powerful effector mechanism of adult neutrophils is the generation of superoxide anion and subsequent oxygen metabolites as a result of the activation of NADPH oxidase. Potent stimulators of the assembly of this enzyme are immune complexes, bacterial products such as fMLP, and complement C5a. Surface immobilized $\mathrm{C} 1 \mathrm{q}$ was also shown to trigger the assembly of this oxidase $(7,27)$, which would provide a mechanism to enhance killing of pathogens to which C1q may be bound. To

Table 1. Myeloid Cell Expression of $C D 93 / C 1 q R_{p}$

\begin{tabular}{lccrcc}
\hline & \multicolumn{3}{c}{ Monocytes } & & \multicolumn{2}{c}{ PMN } \\
\cline { 2 - 3 } \cline { 5 - 6 } & R139* & R3 & & R139 & R3 \\
\hline Cord & $377 \pm 103$ & $* * 872 \pm 162$ & & $43 \pm 35$ & $129 \pm 87$ \\
Adult & $364 \pm 108$ & $* * 648 \pm 138$ & & $64 \pm 26$ & $187 \pm 59$ \\
\hline
\end{tabular}

* Mean fluorescence intensity. Adult $(\mathrm{n}=5)$; cord cells $(\mathrm{n}=7)$.

$* *$ neonate mean $\mathrm{R} 3$ vs adult mean $\mathrm{R} 3, \mathrm{p}=0.028$. 

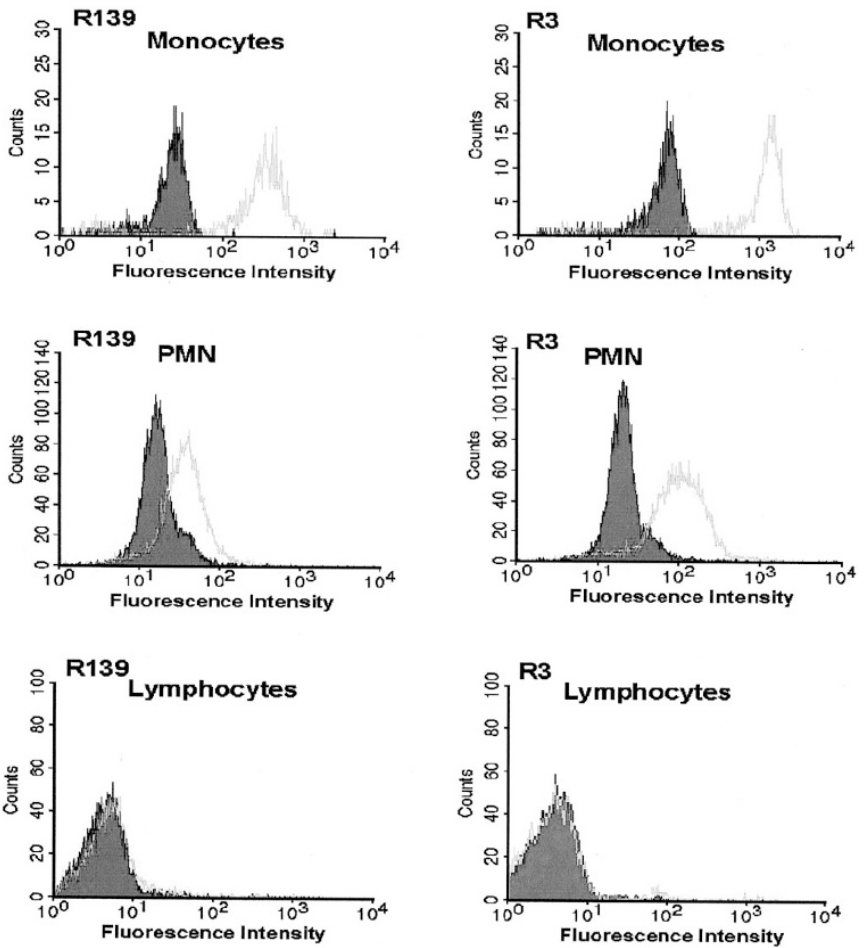

Figure 3. Flow cytometric analysis of $\mathrm{CD} 93 / \mathrm{C} 1 \mathrm{qR} \mathrm{R}_{\mathrm{p}}$ demonstrates expression on neonate monocytes and PMNs. Neonate mononuclear cells and neutrophils were isolated from cord blood and incubated with either isotype control MAb (filled histogram) or anti CD93/C1qR $\mathrm{P}_{\mathrm{P}} \mathrm{MAb}$ (open histogram), R139 (left) or R3 (right). Bound antibodies were detected with secondary FITC labeled anti-mouse antibody. The scatter properties of leukocytes were used to distinguish monocyte and lymphocyte populations in the mononuclear cell preparations to analyze for $\mathrm{CD} 93 / \mathrm{C} 1 \mathrm{qR} \mathrm{P}_{\mathrm{P}}$ cell surface expression levels. Results are representative of 7 experiments.
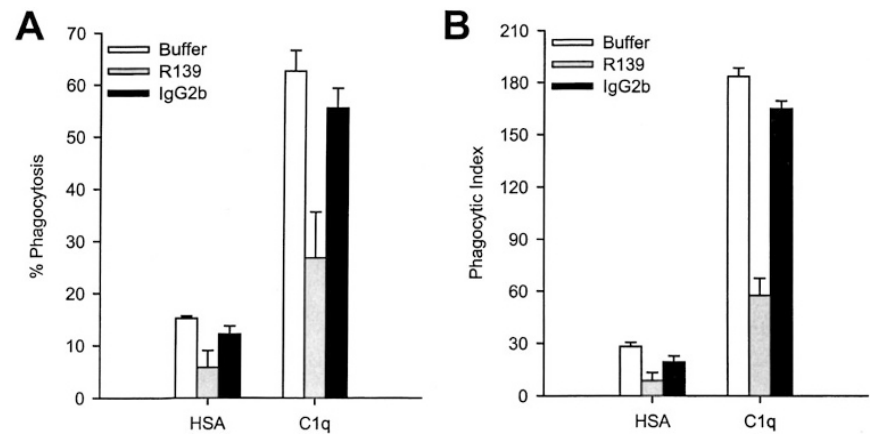

Figure 4. Monoclonal anti-CD $93 / \mathrm{ClqR}$ antibody inhibits C1q-mediated enhancement of phagocytosis. Monocytes purified by flow cytometric sorting were preincubated for $15 \mathrm{~min}$ at room temperature with buffer (open bars), $\mathrm{R} 139$ (anti-CD93/C1qR ${ }_{\mathrm{P}}$ )(dotted bars) or control $\mathrm{IgG}_{2 \mathrm{~b}}$ (solid bars) before addition to chambers precoated with HSA or C1q $(8 \mu \mathrm{g} / \mathrm{mL})$. After $30 \mathrm{~min}$ of adherence, suboptimally opsonized $\mathrm{EA}_{\mathrm{IgG}}$ targets were added and phagocytosis was assayed after $30 \mathrm{~min}$. (A) The percentage of monocytes ingesting at least one $\mathrm{EA}_{\mathrm{IgG}}$ target. $(B)$ The number of targets ingested per 100 monocytes. Data are from one experiment representative of 2 . Error bars indicate the SD of duplicate wells.

determine whether this activity of adult neutrophils also exists in newborns, PMNL were isolated from cord blood and added to 96-well plates coated with C1q or control proteins. Production of superoxide was measured continuously by measuring cytochrome $c$ reduction, spectrophotometrically. Only neutro- phils that were unactivated upon isolation were assessed (28). While the baseline activity of cord blood neutrophils was generally higher than that seen in cells derived from adults $\left(1.86 \pm 0.97\right.$ nmoles superoxide $/ 10^{6}$ cells in cord blood versus $1.13 \pm 0.85$ in adult cells), interaction with $\mathrm{Clq}$ increased by greater than 3 -fold the amount of superoxide produced by either neonate or adult cells $(5.19 \pm 2.47$ nmoles superoxide/ $10^{6}$ cells in cord blood, $\mathrm{n}=4$ versus $3.53 \pm 1.74$ nmoles superoxide $/ 10^{6}$ cells in adults, $n=10$ ). Figure 5 shows a representative kinetic tracing of superoxide production in response to C1q compared with control cells plated in wells precoated with HSA. Lower concentrations of protein used to coat the wells ( 10 and $30 \mu \mathrm{g} / \mathrm{mL}$ ) resulted in lower values for superoxide generation, while little to no further increase in production was detected when higher $(300 \mu \mathrm{g} / \mathrm{mL})$ protein concentration was used to coat the wells (data not shown). Cells from both cord blood and adult cells both responded to the soluble activator phorbol dibutyrate (PDBU) (data not shown).

Levels of C1q and MBL in cord blood. Plasma derived from cord blood was assessed for the levels of C1q and MBL by ELISA. Values presented in Table 2 demonstrate an average of $39.2 \pm 8.3 \mu \mathrm{g} / \mathrm{mL}$ for $\mathrm{C} 1 \mathrm{q}$ (range of $24.2-49.4 \mu \mathrm{g} / \mathrm{mL}$ ). Hemolytic assays performed on a subset of these plasma samples, demonstrated that the cord blood $\mathrm{Clq}$ was as active in a C1q hemolytic assay as adult C1q per $\mu \mathrm{g} \mathrm{C1q}$ (data not shown). In addition, $\mathrm{Clq}$ isolated from pooled cord blood plasma enhanced phagocytosis to a similar extent as $\mathrm{C} 1 \mathrm{q}$ from adult plasma. Thus, neonate $\mathrm{C} 1 \mathrm{q}$ was as active on a per molar basis, as adult $\mathrm{C} 1 \mathrm{q}$. The concentration of MBL in these cord blood sera as measured by ELISA was $1.82 \pm 1.44 \mu \mathrm{g} / \mathrm{ml}$. Interestingly, the values for MBL could be roughly grouped in 4 levels: 4 individuals with levels of $0.15-0.57 \mu \mathrm{g} / \mathrm{mL}, 1$ with $0.8 \mu \mathrm{g} / \mathrm{mL}$, 4 with $1-1.2 \mu \mathrm{g} / \mathrm{mL}$ and 4 with $4-4.37 \mu \mathrm{g} / \mathrm{mL}$, reflecting similar expression differences to that seen in adult sera.

\section{DISCUSSION}

The data presented here are the first demonstration that $\mathrm{Clq}$ can facilitate FcR- and CR1-mediated phagocytosis in cord blood monocytes and trigger superoxide production in cord blood neutrophils, similar to responses seen in adult leukocytes $(4,29)$. It is important to note that the enhancement of phagocytic activity by $\mathrm{Clq}$ is detectable only in conditions where phagocytosis is not maximal, such as with suboptimal opsonization of targets due to a lack of, or limiting amounts of, IgG antibody or complement, conditions which are likely to occur in neonates before complete development of their immune system. While some humoral immunity is derived from the mother, the levels of antibody to specific pathogens can be variable or nonexistent in the neonate. As a result the mechanisms described here may be particularly important in the neonate as protection against infection by microbes.

$\mathrm{Clq}$ is a member of a group of soluble proteins that contain collagen-like amino acid sequences and that play a protective role in host defense. These "defense collagen" proteins are capable of recognizing pathogen-associated molecular patterns 


\section{Cord PMN}

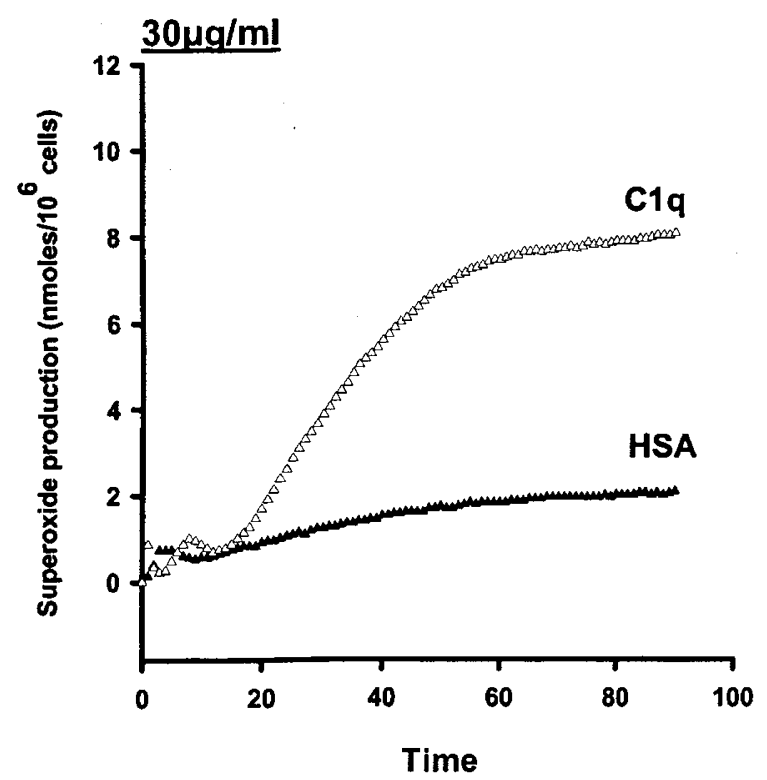

Cord PMN

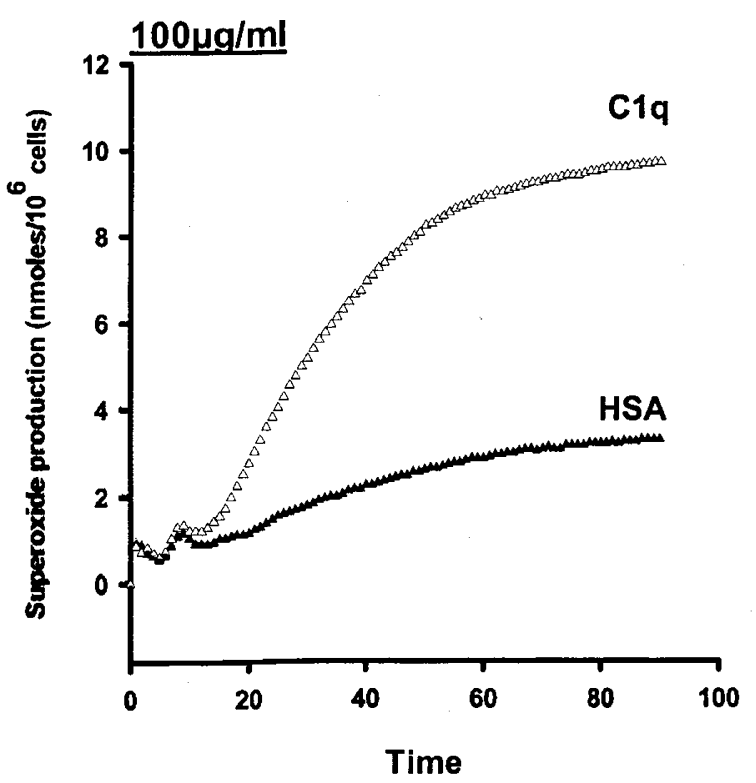

Adult PMN

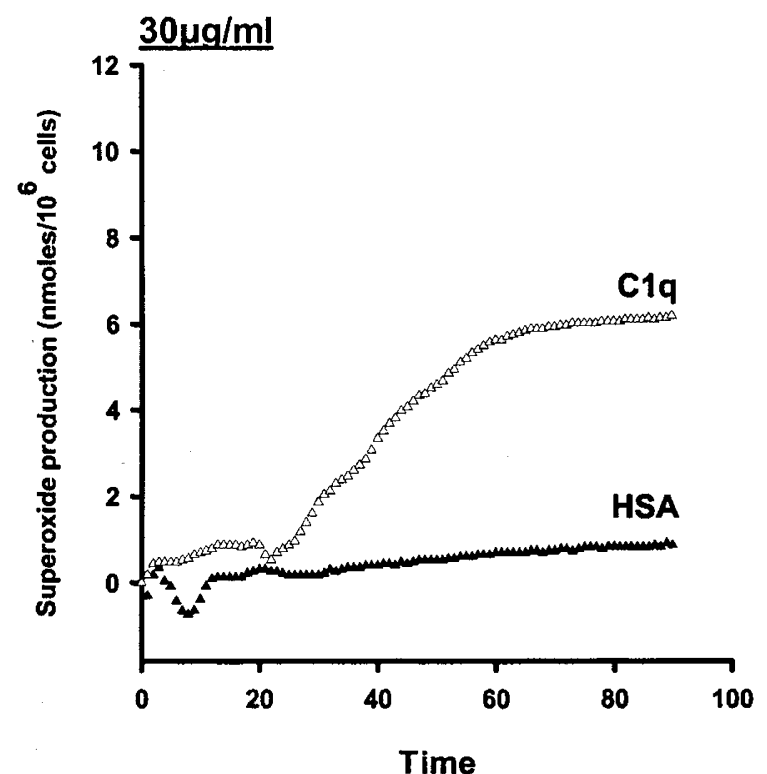

Adult PMN

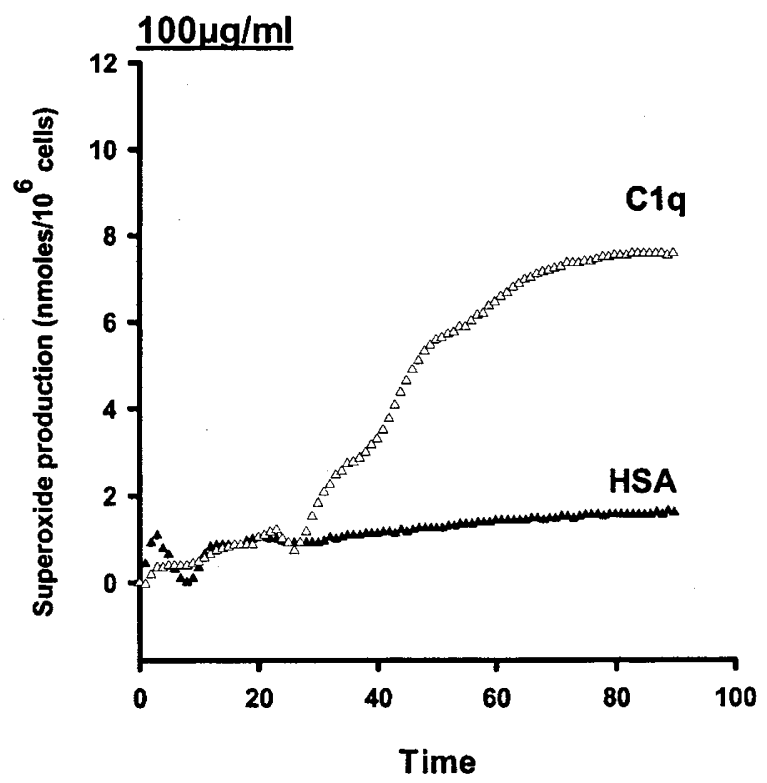

Figure 5. C1q stimulates superoxide generation by cord blood neutrophils. Neutrophils isolated from cord (left) or adult (right) blood were added to microtiter plates coated with $30 \mu \mathrm{g} / \mathrm{mL}$ (top) or $100 \mu \mathrm{g} / \mathrm{mL}$ (bottom) of HSA $(\Delta \Delta \Delta)$ or C1q $(\Delta \Delta \Delta)$ ). Superoxide production by neutrophils was assayed by measuring reduction of cytochrome $c$. The tracings are from one well each condition, representative of reproducible duplicate wells. The data presented are from one experiment representative of four cord blood samples and ten adult blood samples.

(30) and of enhancing phagocytosis of these identified targets (31-33). While it is now accepted that these molecules do interact with and influence the function of phagocytes, little is known about the molecular mechanisms by which $\mathrm{Clq}$ and other defense collagens such as mannose binding lectin, pulmonary surfactant proteins $\mathrm{A}$ and $\mathrm{D}$ and ficolin, trigger this enhancement of phagocytosis. CD $93 / \mathrm{C}_{\mathrm{q}} \mathrm{R}_{\mathrm{P}}$ was originally described as a receptor for $\mathrm{Clq}$ that modulates phagocytosis due to the observations that antibodies recognizing three separate regions of the molecule, blocked the enhancement of phagocytosis by these pattern recognition molecules (reviewed in ref. 4). Here the expression of $C D 93 / C 1 q R_{P}$ was found to be comparable on cord blood monocytes and neutrophils to that on adult cells. 
Table 2. MBL and Clq Levels in Cord Blood Plasma

\begin{tabular}{cccccc}
\hline & \multicolumn{2}{c}{ MBL } & & \multicolumn{2}{c}{ C1q } \\
\cline { 2 - 3 } \cline { 5 - 6 } Case No. & Mean & SD & & Mean & SD \\
\hline 1 & 0.15 & 0.10 & 40.26 & 0.41 \\
2 & 0.34 & 0.04 & 24.97 & 0.69 \\
3 & 0.43 & 0.21 & 46.79 & 1.67 \\
4 & 0.57 & 0.07 & 48.90 & 0.48 \\
5 & 0.82 & 0.08 & 35.26 & 0.42 \\
6 & 1.04 & 0.02 & 38.52 & 3.09 \\
7 & 1.09 & 0.15 & 35.56 & 2.75 \\
8 & 1.12 & 0.18 & 24.17 & 1.46 \\
9 & 1.2 & 0.12 & 49.38 & 0.60 \\
10 & 4.04 & 0.54 & 40.61 & 1.07 \\
11 & 4.21 & 0.25 & 39.89 & 0.92 \\
12 & 4.32 & 0.60 & 36.09 & 0.39 \\
13 & 4.37 & 0.52 & 49.09 & 3.26 \\
Average & 1.82 & 1.44 & 39.19 & 8.29
\end{tabular}

Cases ordered by MBL plasma concentration.

Recently, a mouse model in which the gene for this molecule was ablated has been used to demonstrate that while in vivo these mice are deficient in the clearance of apoptotic cells, in vitro, $\mathrm{CD} 93 / \mathrm{C}_{1 \mathrm{qR}}$ is not required for the cell to respond to $\mathrm{C} 1 \mathrm{q}$ with an enhancement of phagocytosis (3). This suggests that CD93 either regulates phagocytosis initiated by specific signaling pathways differentially (targeted as dangerous by antibody or complement or for clearance only such as with apoptotic cells) or influences adhesion or membrane mobility directly or indirectly. Studies to determine how this surface glycoprotein influences the phagocytic capacity of the cell, and what physiologic role it plays in host defense and/or homeostasis, are ongoing.

Interestingly, levels of $\mathrm{Clq}$ and most other complement components have been shown to be significantly less in newborns than in adults, and we confirm that in the data for $\mathrm{Clq}$ here. For example, while adult $\mathrm{C} 1 \mathrm{q}$ levels are reported to be $70-100 \mu \mathrm{g} / \mathrm{mL}$ serum (34), the cord blood values assessed here were $39 \pm 8 \mu \mathrm{g} / \mathrm{mL}$, similar to those reported for neonates in other studies (35-38). However, the levels of complement components do increase to adult concentrations within days to weeks of birth. MBL levels also increase with gestational age and to an extent after birth (39) (40). However, the constitutive levels of MBL have been shown to vary dramatically in different individuals $(0-5 \mu \mathrm{g} / \mathrm{mL})$ due to distinct allotypes arising from both polymorphisms in the promoter region and mutations in the coding region of the MBL gene (reviewed in ref. 41). Our results demonstrating the variable levels of MBL in neonates with a range of 0.15 to $4.3 \mu \mathrm{g} / \mathrm{mL}$ agrees with data of others $(39,40)$ and reflects the pattern of constitutive MBL levels in adults arising from allotypic variation. Circulating levels of MBL have been shown to increase 2- to 3-fold in individuals with infection or trauma, similar to that of acute phase proteins, and thus consistent with a protective role in defense of the host.

\section{CONCLUSIONS}

In summary, the cellular innate immune responses mediated by $\mathrm{C} 1 \mathrm{q}$, a defense collagen, are functionally as mature in the neonate as in the adult. These results are consistent with reports in the literature of a role for $\mathrm{MBL}$ and $\mathrm{Clq}$ in conferring a significant degree of protection from pathogens until adaptive mechanisms of immunity (antibody and T cell-mediated) become active, and suggest novel possibilities for prophylactic and therapeutic strategies. Interestingly, two recent case studies were reported in which infusions of MBL into adults were shown to be beneficial in restoring opsonic activity in MBLdeficient individuals (42) leading some to suggest that a clinical trial on this potential therapy should be initiated (11), and thus investigations into similar possibilities in neonates at risk may be warranted.

Acknowledgments The authors thank Dr. Stephen Hou, Optical Biology Shared Resource Core Facility, UCI, for advice on and performing the cord blood sorts for monocytes, Christopher Ortiz for technical support, the nursing staff in the Department of Obstetrics and Gynecology at UCIMC and Prof. Kawasaki (Kyoto University, Kyoto, Japan) for native mannose binding lectin.

\section{REFERENCES}

1. Ross SC, Densen P 1984 Complement deficiency states and infection: epidemiology, pathogenesis and consequences of neisserial and other infections in an immune deficiency. Medicine 63:243-273

2. Turner MW, Hamvas RM 2000 Mannose-binding lectin: structure, function, genetics and disease associations. Rev Immunogenet 2:305-322

3. Norsworthy P, Fossati-Jimack L, Cortes-Hernandez J, Taylor P, Bygrave A, Walport MJ, Botto M 2002 Murine CD93 (C1qRP) deficiency causes a defect in apoptotic cell clearance in vivo. Int Immunopharmacol 2:1349

4. Tenner AJ 1999 Membrane receptors for soluble defense collagens. Curr Opin Immunol 11:34-42

5. Ruiz S, Henschen-Edman AH, Nagase H, Tenner AJ 1999 Digestion of C1q collagenlike domain with MMPs-1,-2,-3, and -9 further defines the sequence involved in the stimulation of neutrophil superoxide production. J Leukoc Biol 66:416-422

6. Goodman EB, Anderson DC, Tenner AJ 1995 C1q triggers neutrophil superoxide production by a unique CD18-dependent mechanism. J Leukoc Biol 58:168-176

7. Goodman EB, Tenner AJ 1992 Signal transduction mechanisms of C1q-mediated superoxide production: Evidence for the involvement of temporally distinct staurospore insensitive and sensitive pathways. J Immunol 148:3920-3928

8. Summerfield JA, Sumiya M, Levin M, Turner MW 1997 Association of mutations in mannose binding protein gene with childhood infection in consecutive hospital series. BMJ 314:1229-1232

9. Neth O, Hann I, Turner MW, Klein NJ 2001 Deficiency of mannose-binding lectin and burden of infection in children with malignancy: a prospective study. Lancet 358:614-618

10. Prellner K, Sjoholm AG, Harsten G, Heldrup J, Kalm O, Kornfalt R 1989 C1q and C1 subcomponent complexes in otitis-prone and non-otitis-prone children. A prospective study of children during their first years of life. Acta Paediatr Scand 78:911-917

11. Turner MW 199890 years on: a therapy to 'stimulate the phagocytes'? Scand J Immunol 48:124-126

12. Tenner AJ, Lesavre PH, Cooper NR 1981 Purification and radiolabeling of human C1q. J Immunol 127:648-653

13. Young KR, Ambrus JL, Jr., Malbran A, Fauci AS, Tenner AJ 1991 Complement Subcomponent C1q stimulates immunoglobulin production by human B lymphocytes. J Immunol 146:3356-3364

14. Reid KBM, Lowe DM, Porter RR 1972 Isolation and Characterization of C1q, a Subcomponent of the First Component of Complement, from Human and Rabbit Sera. Biochem J 130:749-763

15. Guan E, Robinson SL, Goodman EB, Tenner AJ 1994 Cell surface protein identified on phagocytic cells modulates the C1q-mediated enhancement of phagocytosis. J Immunol 152:4005-4016

16. Nepomuceno RR, Henschen-Edman AH, Burgess WH, Tenner AJ 1997 cDNA cloning and primary structure analysis of $\mathrm{C} 1 \mathrm{qR}$, the human $\mathrm{C} 1 \mathrm{q} / \mathrm{MBL} / \mathrm{SPA}$ receptor that mediates enhanced phagocytosis in vitro. Immunity 6:119-129

17. Zhao H, Wakamiya N, Suzuki Y, Hamonko MT, Stahl GL 2002 Identification of human mannose binding lectin (MBL) recognition sites for novel inhibitory antibodies. Hybrid Hybridomics 21:25-36

18. Boyum A 1976 Isolation of lymphocytes, granulocytes and macrophages. Scand J Immunol 5(suppl 5):9-15

19. Bobak DA, Gaither TG, Frank MM, Tenner AJ 1987 Modulation of FcR Function by Complement: Subcomponent C1q enhances the phagocytosis of IgG-opsonized targets by human monocytes and culture-derived macrophages. J Immunol 138:11501156 
20. Lionetti FJ, Hunt SM, Valeri CR 1980 Methods of Cell Separation. Plenum Publishing Corp., New York, pp 141-156

21. Bobak DA, Frank MM, Tenner AJ 1986 Characterization of C1q recepto expression on human phagocytic cells: Effects of PDBu and FMLP. J Immuno 136:4604-4610

22. Bohnsack JR, O'Shea JJ, Takahashi T, Brown EJ 1985 Fibronectin-enhanced phagocytosis of an alternative pathway activator by human culture-derived macrophages is mediated by the $\mathrm{c} 4 \mathrm{~b} / \mathrm{c} 3 \mathrm{~b}$ complement receptor (CR1). J Immunol $135: 2680-2686$

23. Bobak DA, Frank MM, Tenner AJ $1988 \mathrm{C} 1 \mathrm{q}$ acts synergistically with phorbo dibutyrate to activate CR1-mediated phagocytosis by human mononuclear phagocytes. Eur J Immunol 18:2001-2007

24. Mayo LA, Curnutte JT 1990 Kinetic microplate assay for superoxide production by neutrophils and other phagocytic cells. Methods Enzymol 186:567-575

25. Tenner AJ, Volkin DB 1986 Complement subcomponent C1q secreted by cultured human monocytes has subunit structure identical with that of serum C1q. Biochem J 233:451-458

26. Arora M, Munoz E, Tenner AJ 2001 Identification of a Site on Mannan-binding Lectin Critical for Enhancement of Phagocytosis. J Biol Chem 276:43087-43094

27. Ruiz S, Henschen-Edman AH, Tenner AJ 1995 Localization of the site on the complement component $\mathrm{C} 1 \mathrm{q}$ required for the stimulation of neutrophil superoxide production. J Biol Chem 270:30627-30634

28. Weinschenk NP, Farina A, Bianchi DW 1998 Neonatal neutrophil activation is function of labor length in preterm infants. Pediatr Res 44:942-945

29. Eggleton P, Reid KBM, Tenner AJ 1998 C1q-how many functions? How many receptors? Trends Cell Biol 8:428-431

30. Medzhitov R, Janeway CA, Jr 1997 Innate immunity: impact on the adaptive immune response. Curr Opin Immunol 9:4-9

31. Mariencheck WI, Savov J, Dong Q, Tino MJ, Wright JR 1999 Surfactant protein A enhances alveolar macrophage phagocytosis of a live, mucoid strain of $P$-aeruginosa. Am J Physiol Lung Cell Mol Physiol 277:L777-L786
32. LeVine AM, Kurak KE, Wright JR, Watford WT, Bruno MD, Ross GF, Whitsett JA Korfhagen TR 1999 Surfactant protein-A binds group B Streptococcus enhancing phagocytosis and clearance from lungs of surfactant protein-A- deficient mice. Am J Respir Cell Mol Biol 20:279-286

33. Kuhlman M, Joiner K, Ezekowitz RAB 1989 The Human Mannose-Binding Protein Functions as an Opsonin. J Exp Med 169:1733-1745

34. Ziccardi RJ, Cooper NR 1978 Direct demonstration and quantitation of the first complement component in human serum. Science 199:1080-1082

35. Wolach B, Dolfin T, Regev R, Gilboa S, Schlesinger M 1997 The development of the complement system after 28 weeks' gestation. Acta Paediatr 86:523-527

36. Johnston RB, Jr 1986 The complement system: physiology, disorders, and activity in the newborn infant. Mead Johnson Symp Perinat Dev Med 24:7-12

37. Yonemasu K, Kitajima H, Tanabe S, Ochi T, Shinkai H 1978 Effect of age on C1q and $\mathrm{C} 3$ levels in human serum and their presence in colostrum. Immunology 35:523-530

38. Johnson U, Truedsson L, Gustavii B 1983 Complement components in 100 newborns and their mothers determined by electroimmunoassay. Acta Pathol Microbiol Immunol Scand [C] 91:147-150

39. Terai I, Kobayashi K 1993 Perinatal changes in serum mannose-binding protein (MBP) levels. Immunol Lett 38:185-187

40. Lau YL, Chan SY, Turner MW, Fong J, Karlberg J 1995 Mannose-binding protein in preterm infants: developmental profile and clinical significance. Clin Exp Immunol 102:649-654

41. Petersen SV, Thiel S, Jensen L, Steffensen R, Jensenius JC 2001 An assay for the mannan-binding lectin pathway of complement activation. J Immunol Methods 257:107-116

42. Valdimarsson H, Stefansson M, Vikingsdottir T, Arason GJ, Koch C, Thiel S, Jensenius JC 1998 Reconstitution of opsonizing activity by infusion of mannanbinding lectin (MBL) to MBL-deficient humans. Scand J Immunol 48:116-123 